\title{
Differential Metabolites Markers from Trunking and Stressed Non-Trunking Sago Palm (Metroxylon sagu Rottb.)
}

\author{
Hasnain Hussain ${ }^{1, * \#, ~ W e i-J i e ~ Y a n ~}{ }^{1, \#}$, Zainab Ngaini $^{2}$, Norzainizul Julaihi ${ }^{3}$, Rina Tommy ${ }^{3}$, \\ Showkat Ahmad Bhawani ${ }^{2}$
}

${ }^{I}$ Centre for Sago Research (CoSAR), Faculty of Resource Science and Technology, Universiti Malaysia Sarawak, 94300 Kota Samarahan, Sarawak, Malaysia; ${ }^{2}$ Faculty of Resource Science and Technology, Universiti Malaysia Sarawak, 94300 Kota Samarahan, Sarawak, Malaysia; ${ }^{3}$ Land Custody and Development Authority (PELITA), Level 4, 8 \& 12, Wisma Satok, Jalan Satok, 93400 Kuching, Sarawak, Malaysia

\begin{abstract}
Background: Sago palm is an important agricultural starch-producing crop in Malaysia. The trunk of sago palm is responsible for the the starch to reach maturity for harvesting after ten years. However, there are sago palms that fail to develop thier trunk after 17 years of being planted. This is known as a stressed "non-trunking" sago palm, which reduces the economic value of the palms.

Objective: The study was initiated to compare the differences in metabolite expression between trunking and non-trunking sago palms and secondly to determine the potential metabolite-makers that are related to differential phenotypes of sago palms.

Methods: Metabolites were extracted using various solvents and analysed using NMR spectroscopy and GC-MS spectrometry. Data obtained were subjected to principal component analysis.

Results: The study determined differential metabolites expression in the leaf extracts of normal trunking sago palm compared to the non-trunking palms. Metabolite groups differently expressed between trunking and non-trunking sago palm are oils and waxes, haloalkanes, sulfite esters, phosphonates, phosphoric acid, thiophene ester, terpenes and tocopherols. GC-MS analysis of Jones \& Kinghorn extraction method determined two sets of metabolite markers, explaining the differences in metabolites expression of trunking and nontrunking sago palms in ethyl acetate and methanol extract of $89.55 \%$ comprising sulfurous ester compounds and $87.04 \%$ comprising sulfurous ester, sulfurous acid and cyclohexylmethyl hexyl ester, respectively.

Conclusion: Two sets of metabolite markers were expressed in the trunking and nontrunking sago palms. These metabolites can potentially be used as markers for identifying normal and stressed plants.
\end{abstract}

Received: May 16, 2020

Revised: August 22, 2020

Accepted: September 03, 2020

DOI:

10.2174/2212796814999200930120925

Keywords: Non-trunking, sago, metabolites, differential expression, Metroxylon sagu, metabolite markers.

\section{INTRODUCTION}

Metroxylon sagu Rottb., commonly known as sago palm, belongs to the family of Palmae, and

\footnotetext{
*Address correspondence to this author at the Centre for Sago Research (CoSAR), Faculty of Resource Science and Technology, Universiti Malaysia Sarawak, 94300 Kota Samarahan, Sarawak, Malaysia; Tel/Fax: ++60-82-583012/++60-82-583160;

E-mail: hhasnain@unimas.my

${ }^{\#}$ Both authors contributed equally to this manuscript.
}

subfamily Calamoideae [1]. It has long been cultivated as an agricultural crop in Malaysia mainly in Sarawak state, as well as throughout the Southeast Asia regions, especially in Papua New Guinea and Indonesia. Compared with other species of genus Metroxylon such as $M$. vitiense Benth., $M$. amicarum Beccari, $M$. paulcoxii McClatchey and $M$. salomonense Beccari [2], only M. sagu is both hapaxanthic indicating the excessive storing of 